\title{
Investigate Temperature Preheating on the Chill Plate to Identify Surface Characteristic on the Ductile Iron by Sand Casting
}

\author{
F. G. Natalino, Rusnaldy, W. Achmad and S. Arif
}

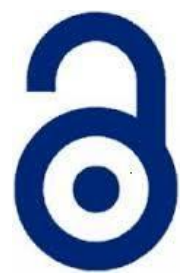

Received: 27 February 2021

Accepted: 30 April 2021

Published: 15 July 2021

Publisher: Deer Hill Publications

(c) 2021 The Author(s)

Creative Commons: CC BY 4.0

\begin{abstract}
The chilled casting method is widely used in the metal casting industry to accelerate the mold's cooling rate. This method is very suitable for surface hardening by depositing the elements contained in the chill material onto the surface of the object being cast. One of the factors that influence surface hardness characteristics is the diffusion temperature. This study aims to determine the microhardness, surface layer thickness, and the element contained on the surface. The main material produced into Y-Block is ductile cast iron, the chill material is SS 304 plate with a thickness of $0.2 \mathrm{~mm}$. However, before the liquid material is poured into a mold, the chill plate is inserted into the surface of the pattern in the mold, then the plate was preheated. The result showed that the highest preheating temperature has produced microstructure around the surface area namely eutectic carbide of $(\mathrm{FeCr})_{7} \mathrm{C}_{3}$, and $(\mathrm{FeCr})_{3} \mathrm{C}$. SEM-EDX analysis shows that $7.13 \% \mathrm{Cr}$ is contained on the coating layer at a thickness of $0.020 \mathrm{~mm}$ and an average hardness of 700-900 HV.
\end{abstract}

Keywords: Chill, Casting, Surface Hardening, Diffusion, Preheating.

\section{INTRODUCTION}

In the metal foundry industry, the chilled casting method is used to harden the specimen surface hence it is resistant to high wear. Chill is a high thermal conductivity material or component used to accelerate the cooling of metal in the mold. Its use also increases productivity level, improves product defects in the surface area, and enhances the casted product's mechanical properties [1,2]. The important factor to consider when using the chill for the surface hardening process is the composition structure in the material deposited onto the surface of the object being cast. Therefore, to understand the formation of a deposited crystal structure that forms on the surface of the object, it is necessary to consider several phenomena, such as thermal, hydrodynamic, and physico-chemical [3]. Until now, the chill has been widely used in aluminium, steel, and cast-iron casting. In aluminium casting, it is used to increase the rate of heat transfer from the surface of the chill to the object being cast and increase high hardness and smooth grain structures. The thicker the chill used, the greater the heat absorbed to the surface. Therefore, in the solidification step, the casting material tends to cool more slowly at the centre area but quickly cools in the surface area [4-7]. Cantavel et al. applied the chill method to steel casting. It is also used to characterize the surface of grey cast iron to make it hard. Hardness is formed due to the diffusion of $\mathrm{Cr}, \mathrm{Ni}$, Cu granular structures and other element content, thereby leading to the formation of white iron on the surface through very fast cooling [8-10]. Chill can also be applied to camshaft casting using grey cast iron materials and ductile cast iron type GJS-400 used to increase cooling speed and the nodule count, thereby improving the microstructural properties [11, 12] and forming a eutectic carbide structure based on the alloying of the elements $\mathrm{Cr}$, Mo, and Ti through fast cooling rates [13-15]. Manganese elements can also be used to make chills in ductile iron castings; however, they are unable to overcome the high hardness of the component surfaces to wear-resistant [1]. One of the materials commonly used for made the chill is copper or cast iron. The chill is placed on the surface of the pattern hole in the mold to adjust the fast-cooling rate on the surface of the specimen to be cast [16]. Chill is made of copper material and combined with $1.5 \% \mathrm{Cr}$ to produce Ferro carbide, thereby making it to wear and abrasion resistant. Chill is usually used to coat the mold walls, hence the

F. G. Natalino', Rusnaldy ${ }^{2}$, W. Achmad² and S. Arif ${ }^{3}$

'Department of Mechanical Engineering, Dili Institute of Technology, Aimeti Laran Street, Dili - Timor Leste

'Doctorate Program, Department of Mechanical Engineering, Diponegoro University, Tembalang, Semarang 50275 , Indonesia

${ }^{2}$ Department of Mechanical Engineering, Diponegoro University, Tembalang, Semarang 50275, Indonesia

${ }^{3}$ Politeknik Manufacture Ceper-Jawa Tengah Indonesia

E-mail: natalinofonseca81@gmail.com

Reference: Natalino et al. (2021). Investigate Temperature Preheating on the Chill Plate to Identify Surface Characteristic on the Ductile Iron by Sand Casting. International Journal of Engineering Materials and Manufacture, 6(3), 141-151. 
liquid poured into the mold tends to rapidly transform the cooling process until there is fast solidification in the outer layer of the specimen. In this way, a dendritic granule structure easily forms in the skin layer due to the touch between the chill-coated mold wall and the solid specimen at high temperatures [17]. This is similar to the method used by Ma Qian et al, [18] whereby the mold walls were coated with SS 304 plate with the melted material poured into the mold. The result is the formation of eutectic carbides, namely $(\mathrm{FeCr})_{7} \mathrm{C}_{3},(\mathrm{FeCr})_{3} \mathrm{C}, \mathrm{M}_{3} \mathrm{C}$, and $\mathrm{M}_{7} 7 \mathrm{C}_{3}$. This eutectic carbide alloys formed are dependent on the chemical composition and cooling rate during solidification [19, 20]. The principle for the formation of iron carbide on the surface due to chill casting occurs towing to diffusion, which is a change in the composition of the deposited interfaces in the absence of the compound. Factors that greatly influence the diffusion process are temperature and chemical bonding, where the higher of diffusion temperature, the better the binding ability of the deposited structure. Low diffusion temperatures tend to have an adverse effect on hardened surfaces, thereby leading to surface morphology. Furthermore, morphological characterization occurs by compacting and creating a needle-shaped hole in the surface. An atom's mobility on a surface depends on its energy, atom-surface interactions (chemical bonding), and surface temperature [21, 22]. As research conducted by M. Ramadan, the annealing temperature above $700^{\circ} \mathrm{C}$ and holding time of 180 min will diffuse the $\mathrm{Cr}-\mathrm{Ni}-\mathrm{C}$ element on the surface of the ductile iron, thereby increasing the hardness of the outer skin layer [23]. As for research from Shi, $\mathrm{Z}$ et al, using Fe-Cr-C as a hardfacing alloy then doped with Ce elements to increase the ductility and toughness of materials, but it still did not increase the high hardness on the surface [24]. Also, the element chromium is commonly used to bond preferentially to other elements to increase the hardness of the material $[25,26]$. Therefore, based on these reasons, the authors tried to perform surface hardening of the martensitic ductile cast iron material using the chilled casting method. The application of chilled cast iron focuses on the diffusion system between the chill material and the object surface. Moreover, the atomic structure's attachment diffused from the chill material is influenced by the temperature in the area of interaction between the chill and the object surface. But there is also a research question that does the use of preheating on chill affect the hardness of the material, the thickness of the deposited atomic layer, and the formation of the microstructure? Then the researchers decided the purpose of this study is to determine the microhardness, surface layer thickness, and the element contained on the surface with the difference in preheating temperature parameters that are distributed to the chill plate before the pouring process.

\section{MATERIALS PREPARATION AND EXPERIMENTAL PROCEDURE \\ 2.1 Material Preparation}

The melting materials used to form martensitic ductile iron are scrap steel and iron. The ductile iron utilized in this study has a grade of 120-90-02 according to ASTM A536 standards, which is recommended for users to make wearresistant components such as gears, crankshafts, and others [27, 28]. Furthermore, the shape of the casted sample is Y-Block, as shown in Figures $1 \mathrm{a}$ and 1b, coded from $\mathrm{S1}$ to $\$ 4$. The material used to design the chill is austenitic stainlesssteel SS 304 plate with chemical composition, as shown in Table 1. This composition material has according to standard ASTM A240 [29].

Table 1: Chemical composition of the stainless steel 304 sheet, ASTM A 240 [29].

\begin{tabular}{cccccc}
\hline $\mathrm{C}$ & $\mathrm{Si}$ & $\mathrm{Mn}$ & $\mathrm{Ni}$ & $\mathrm{Cr}$ & $\mathrm{Fe}$ \\
\hline 0.059 & 0.27 & 1,37 & 4,9 & 19,34 & 72,78 \\
\hline
\end{tabular}

\subsection{Chill Design Process and Its Use}

The chill size and shape, according to the casted specimen as show in Figure 1. The chill plate to be inserted into each specimen is one sheet, and the total number prepared for the $4 \mathrm{Y}$-Block specimens to be produced is 4 sheets. The chill manufacturing process is SS 304 plate cut into rectangles with a length and width of $270 \mathrm{~mm}$ and $25 \mathrm{~mm}$ and bent according to the specimen shape. The number of chill plates according to the variation of the preheating temperature, is shown in Table 2.

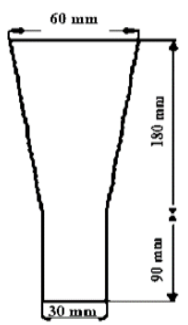

(a)

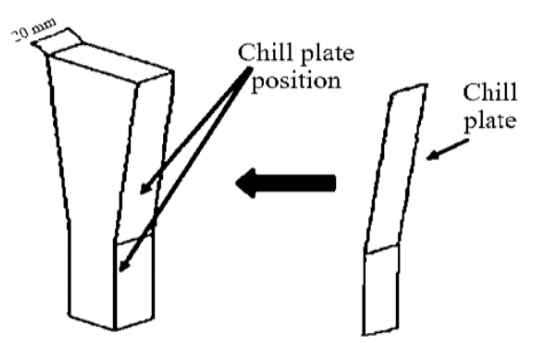

(b) (c)

Figure 1: Pattern and chill plate; (a) the type and dimension of pattern; (b) 3D view of the pattern and position chill plate on the pattern; $(c)$ chill plate. 
Table 2: Preheating parameters to identify different sample group.

\begin{tabular}{ccc}
\hline Code of Sample & The thickness of the Ss 304 plats & Preheating to surface of chill plate $\left(^{\circ} \mathrm{C}\right)$ \\
\hline S1 & $0.2 \mathrm{~mm}$ & $500^{\circ} \mathrm{C}$ \\
S2 & $0.2 \mathrm{~mm}$ & $700^{\circ} \mathrm{C}$ \\
S3 & $0.2 \mathrm{~mm}$ & $900^{\circ} \mathrm{C}$ \\
S4 & $0.2 \mathrm{~mm}$ & Not Preheating \\
\hline
\end{tabular}

\subsection{Mold Preparation}

The mold is made of wooden slabs with a thickness of $20 \mathrm{~mm}$ then formed into a box model with width, length and depth of $200 \mathrm{~mm}, 300 \mathrm{~mm}$ and $300 \mathrm{~mm}$ respectively as show in Figure 2. Furthermore, the mold box is filled with high mesh class silica sand, mixed with water glass and methanol liquid, and stirred to homogeneity. In the next process, silica sand is poured into a box to create a hole trace pattern in accordance with the planned specimen shape and dried with $\mathrm{CO}_{2}$ gas. However, before the silica sand is poured into the mold, the chill plate, Y-Block pattern, and thermocouple cable were first attached to the surface and positioned in the mold as show in Figures $2 \mathrm{a}$ and $2 \mathrm{~b}$. This research made use of the HT-9815 thermocouple thermometer with 4 cables embedded into the sand and touched the surface of the chill plate. The function is used to detect the preheating temperature on the surface of the chill plate.

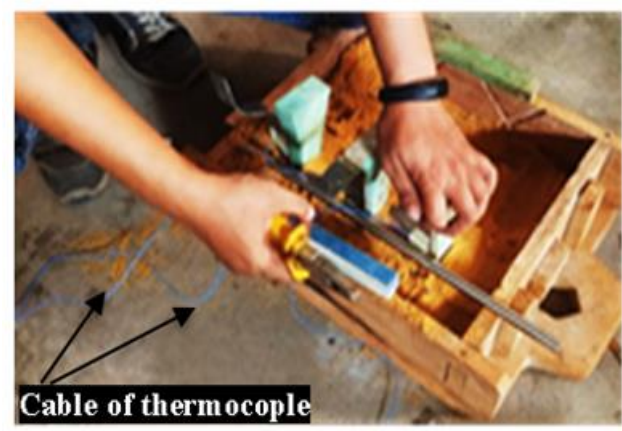

(a)

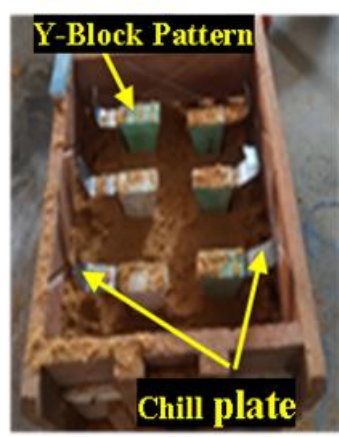

(b)

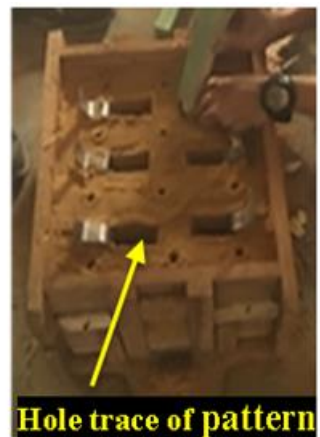

(c)

Figure 2: Model of molding and specimen adjustment procedure. a) thermocouple cable installation touched to the chill plate; b) the sample arranged in the mold; c) plate chill condition on the surface of a tracing pattern.

\subsection{Preheating Technique and Pouring Process}

The pouring process is carried out after the chill plate is preheated according to the sample code given as show in the Table 2. It comprises three LPG gas cylinders and one $\mathrm{O}_{2}$ tube. The flow of gas and oxygen is sprayed through the four torch gas blenders that have been provided to point to the chill plate surface. Hence the flame emitted to the plate surface needs to reach the target temperature. Furthermore, nodular cast iron material, which has been melted at a temperature of $1500^{\circ} \mathrm{C}$ and was inoculated with $0.3-0.7 \%$ Fe-Si alloy then poured into the mold simultaneously.

\section{Testing and Analysis}

\subsection{Microstructure and Mechanical Properties Examination}

The microstructure analysis is based on the ASTM 247 procedure, using an Olympus BX41M optical microscope. After cutting, the specimen is polished with sandpaper $(400,800,1500$, and 2000$)$, then etched with nital $98 \mathrm{~mL}$ ethanol and $2 \mathrm{~mL}$ nitric acid $\left(\mathrm{HNO}_{3}\right)$ based on the test guide on ASM Handbook Vol. 9. The sample is cut without being exposed to high heat. Furthermore, the sample size for the microstructure analysis and microhardness Vickers test is $10 \times 10 \times 6 \mathrm{~mm}[30,31]$. The test point areas are taken from each Y-Block specimen of six products as show in the Table 2, and it has been given the codes of D1, D2, D3, and D4 and are cut in different areas as shown in Figure 3a. These points are carried out on two sides, namely right site $A$ and left site $B$, and each zone for each test sample has 9 test points, as shown in Figure $3 b$.

Figure $3 \mathrm{~b}$ shows that there are three group test focus locations, and each has three points. Therefore, the total number of test points of microhardness Vickers for each of all specimens ( $\$ 1, S 2, S 3$, and $\$ 4)$ is 72 , then the results are summed to take the average value. Testing for microhardness Vickers using the Mitutoyo HM-200, a Vickers indenter and a $200 \mathrm{gf}$ load is used to determine the diffusion area's hardness layer. The test area in each sample for microhardness testing is the same as the microstructure. However, the distance between one test point and another is according to 
standard ASTM E92 [32] about standard test method for Vickers hardness of metallic materials, the microhardness test point starts from the edge towards the centre, and the number of indenter focus is three.

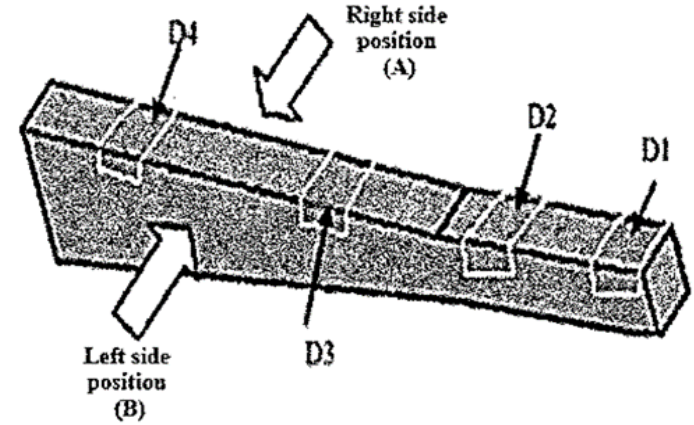

(a)

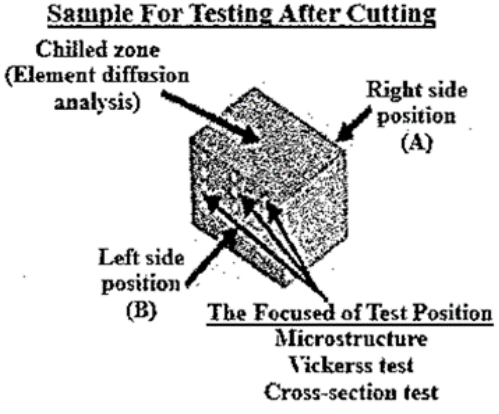

(b)

Figure 3: Microstructure and microhardness Vickers testing zone for every specimen Y-Block (a) location for focus analysis point (b) total of analysis point for each site zone (right site zone and left site zone) and for all sample testing after cutting.

\subsection{Coating and Chemical Distribution Analysis}

The chemical composition of the ductile iron material that has been analyzed is in the middle area of the specimen. One Y-Block sample was taken to represent the entire specimen. The type of machine used is the ARL Optic Emission Spectrometer and types Switzerland QTD-17. SEM-EDX is used to identify contaminated or unknown particle interactions between two materials from ductile cast iron and austenitic stainless steel (SS 304). The expected results are the percentage of element content deposited in the surface area will be detected by EDX, and the coating layer's thickness on the surface measured by cross-section proses. Furthermore, the measurement process for the diffusion thickness layer was processed by ImageJ, then measurements were taken ten times to take the average value. SEMEDX type used is JEOL - JSM-6510LA under a voltage of $20 \mathrm{kV}$ and a working distance of $16 \mathrm{~mm}$. Analysis samples for cross-section and target diffusion are taken in the same area as the microhardness test as show in Figure $3 \mathrm{~b}$.

\section{RESULTS AND DISCUSSION}

\subsection{The Result of Chemical Composition on The Ductile Iron}

The chemical composition contained in the Y-Block ductile iron material includes $3.75 \% \mathrm{C}, 0.47 \% \mathrm{Mn}, 2.03 \% \mathrm{Si}$, $0.04 \% \mathrm{Cr}, 0.17 \% \mathrm{Ni}, 0.07 \% \mathrm{Mo}, 0.15 \% \mathrm{Cu}, 0.02 \% \mathrm{P}, 0.15 \% \mathrm{Ce}, 0.06 \% \mathrm{Mg}$ and the other is $\mathrm{Fe}$. The results of this chemical composition analysis have responded to the material specifications for ductile cast iron according to standard of ASTM A 536 [27], which is recommended for the manufacture of wear-resistant components such as wheel pinions, gears, rollers and slides, these components are hard and wear-resistant on the surface but in the middle area must be ductile.

\subsection{The Formation of Microstructure at The Centre Zone}

The microstructure analysis process associated with this research was carried out on the surface and the center zone. The microstructure found in the center zone for all samples (S1, S2, S3 and S4) shows that graphite nodules are uniformly and roundly formed, with a ferrite and perlite structure phase, as shown in Figure 4. This graphite structure is under the specifications of the nodular cast iron material according to the ASTM A 536 standard [27] which is carried out through an inoculation process. In this nodularization process, magnesium $(\mathrm{Mg})$ alloy elements will be added to get a round of the graphite nodule so that the ductile iron base material can withstand tensile loads and impact loads according to researchs Sasaki et al. [33] and Yamamoto $S$ et al. [34]. 


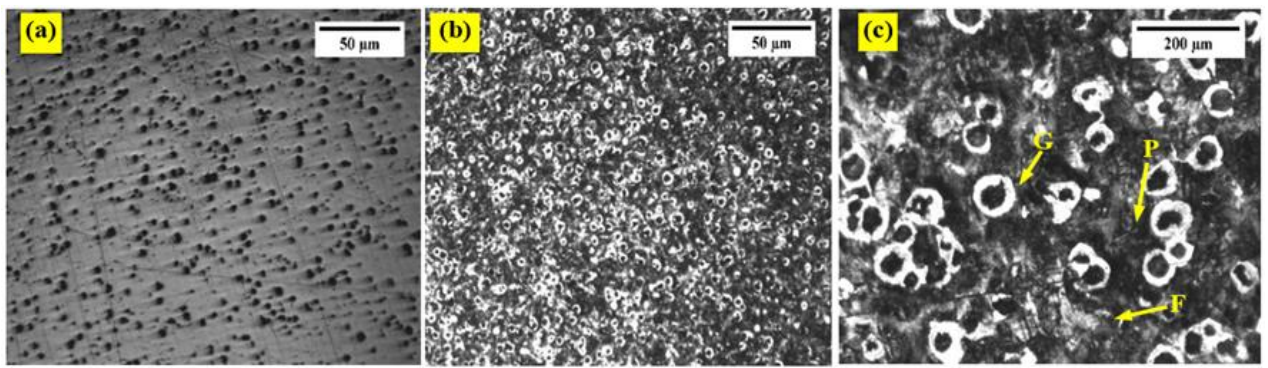

Figure 4: (a) Uniformity of graphite nodules before etched; (b) Graphite nodule growth uniformly after etched and microscopic magnification 50x, (c) Uniformity of graphite nodules with microscopic magnification 200x (G: graphite nodule, P: perlite and F: $\alpha$-Ferrite).

The microstructure found in the surface and the centre area is different. Figure 5 shows that the microstructure formation on specimen $\$ 4$ is average and consists of a fully ferritic-matrix microstructure. Therefore, with the rapid cooling process, eutectic carbide formation and a microstructure containing cementite, ferrite, and pearlite are very uniform and compact on the surface area. The use of fast cooling leads to the formation of graphite flakes, also known as martensite, in the surface area. The formation of this matrix structure is due to rapid cooling with the use of chill, therefore cementite occurs as a separate constituent in the matrix. In other cases, no diffusion layer was seen between the chill and the ductile iron interface.

\subsection{The Formation of Microstructure at The Surface}

The microstructure found in the surface and the center area is different. Figure 5 show that the microstructure formation on specimen $\$ 4$ is average and consists of a fully ferritic-matrix microstructure. Therefore, with the rapid cooling process, eutectic carbide formation and a microstructure containing cementite, ferrite, and pearlite are very uniform and compact on the surface area, as explained by Riposan L. et al. [25] that the graphite carbide structure is formed at the end of the solidification step in the ductile iron casting process [35, 36]. This occurs due to the rapid cooling of the interface through contraction between the cast liquid and the mold wall. The use of fast cooling leads to the formation of graphite flakes, also known as martensite, in the surface area. The formation of this matrix structure is due to rapid cooling with the use of chill, therefore cementite occurs as a separate constituent in the matrix. In other cases, no diffusion layer was seen between the chill and the ductile iron interface.

The microstructure results for Sample $\mathrm{S} 1$ are shown in Figure 6, using a preheating temperature of $500^{\circ} \mathrm{C}$, with very uniform Ferro carbide in the edge area. Also, the phase structure is randomly formed around the graphite nodule, which is visible because the main material used for all cast specimens is ductile iron. Therefore, chill uses SS 304 material dominated by the composition elements of $19.34 \% \mathrm{Cr}$ and $4.9 \% \mathrm{Ni}$ (Table 1). Furthermore, at the interfacial austenite temperature, the chill and ductile iron succeeded in depositing $\mathrm{Cr}$ and $\mathrm{Ni}$ elements onto the ductile iron surface. The coating area is found to be a primary eutectic carbide or $\mathrm{Cr}$-carbide structure and is defined as $(\mathrm{FeCr})_{3} \mathrm{C}$, where more details are explained in the EDX analysis results. According to Vander Voort and Baldwin, chromium carbide is formed with the cooling rate of solidification and the $5 \% \mathrm{Cr}$ composition. This carbide structure characteristic is very good for high wear-resistant [37].

Figures 7 describe the sample $\$ 2$ and the parameters using a preheating temperature of $700^{\circ} \mathrm{C}$. The type of microstructure formed in the edge area is similar to the $S 1$ sample, which is dominated by Ferro carbide. The phase structure found near the coating area, and the perlite phase around the graphite nodule was acicular ferrite. A ledeburite phase forms in areas far from the diffusion region, while a structure eutectic carbide, also known as a white cast iron layer, is formed in the coating area. The eutectic carbide structure is called $(\mathrm{FeCr})_{7} \mathrm{C}_{3}$, and this structure is formed due to the diffusion of the $\mathrm{Cr}$ and $\mathrm{Ni}$ structures contained in the chill material at a preheating temperature of $700^{\circ} \mathrm{C}$. The higher preheating temperature used in the chilled casting process has minimized the cooling rate at the chill and ductile iron interface, thereby preventing the formation of the iron carbide structure over low surface areas.

The microstructure formation on the surface of the $\$ 3$ specimen using the preheating temperature of $900^{\circ} \mathrm{C}$ as shown in Figure 8, that the average microstructure consists of ferrous carbide and acicular ferrite near the diffusion zone with the small number of martensite phases. The microstructure growth in the diffusion zone is a very large eutectic carbide called $\left(\mathrm{FeCr}{ }_{7} \mathrm{C}_{3}\right.$ because the element $\mathrm{Cr}$ diffuses too much to the surface. Meanwhile, Figure $8 \mathrm{c}$ shows that the diffusion layer formed on the surface has been shifting inward, this layer is the ledeburite phase or the socalled white cast iron layer which is dominant in the surface layer. These results as discussed by Elorz P-Sanz et al. [38]. Diffusion element and layer thickness is discussed in the EDX analysis. 

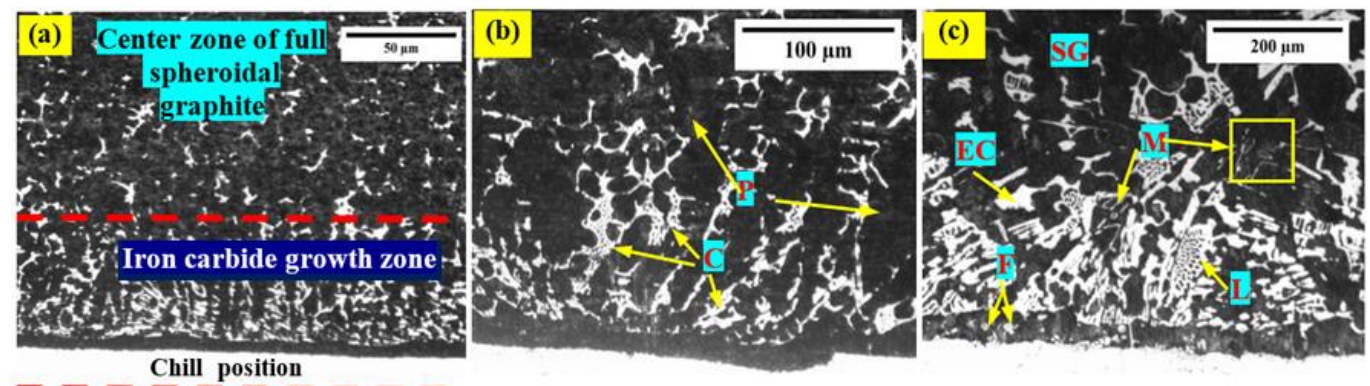

Figure 5: Average microstructure formation on the surface of the samples (\$4). (a. microscopic magnification 50x; b. microscopic magnification 100x, c. microscopic magnification 200x). $(P=$ perlite; $C=$ cementite; $E C=$ eutectic carbide; $\mathrm{M}=$ martensite; $\mathrm{L}=$ ledeburite; $\mathrm{F}=$ ferrite; $\mathrm{SC}=$ spheroidal graphite).
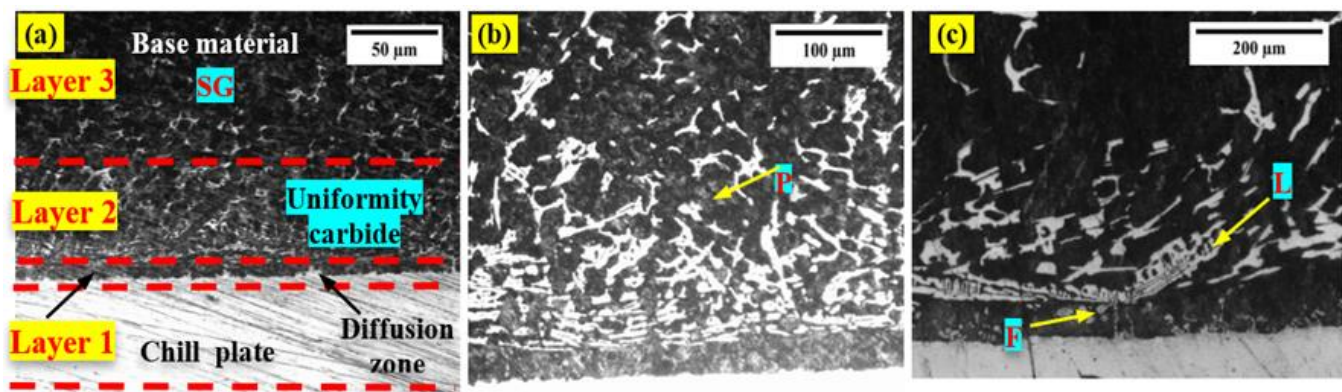

Figure 6: Average microstructure formation on the surface of the samples (S1). (a. Sample $S 1$ microscopic magnification

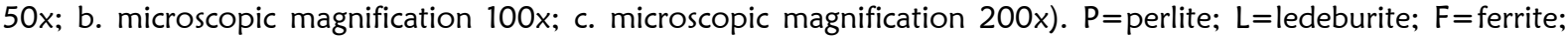
$S G=$ spheroidal graphite).
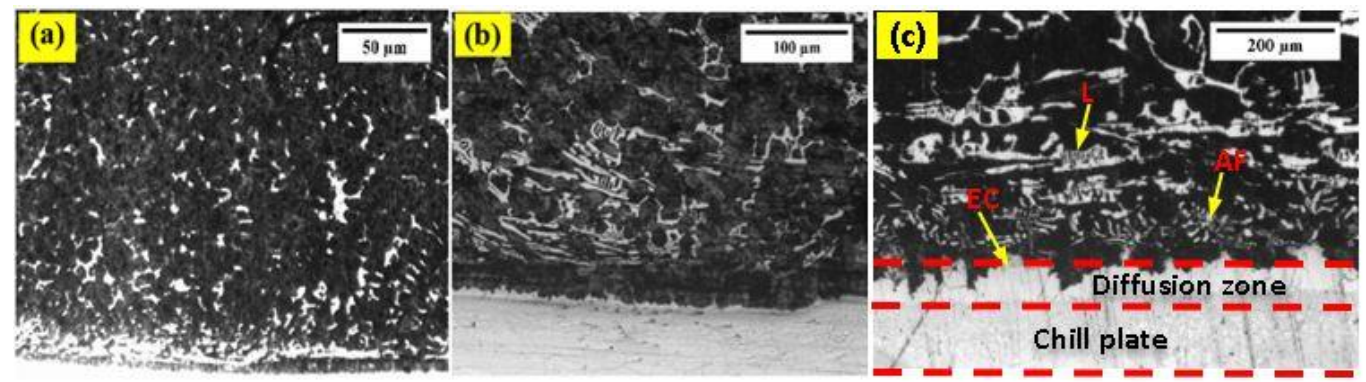

Figure 7: Average microstructure formation on the surface of the $\$ 2$ samples. (a. Sample $\$ 1$ microscopic magnification 50x; b. microscopic magnification 100x; c. microscopic magnification 200x). (AF=Acicular ferrite, EC=eutectic carbide; $\mathrm{L}=$ ledeburite.
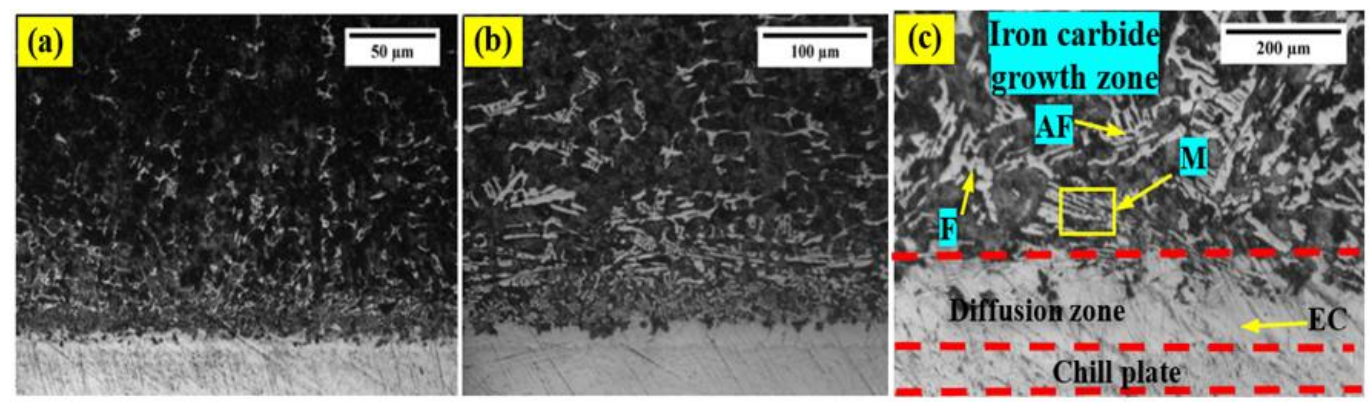

Figure 8: Average microstructure formation on the surface of the $\$ 3$ samples. (a. Sample $\$ 1$ microscopic magnification 50x; b. microscopic magnification 100x; c. microscopic magnification 200x). (AF = Acicular ferrite, EC=eutectic carbide; $M=$ martensite; $F=$ ferrite). 


\subsection{EDX and Microhardness Vickers Test}

The results of SEM-EDX are taken from different temperature parameters, then they will be compared between the use of low and high temperatures preheating. Also, samples using the preheating will be compared with samples that do not use the preheating. During the EDX measurement, different areas were focused and the corresponding peaks are shown in Figure 9 and 10. The results of samples that did not use preheating (\$4) on the plate chill before the pouring process were elements of chromium and nickel which diffused onto the surface of the ductile iron is $0.08 \%$ $\mathrm{Cr}$ and $0.06 \% \mathrm{Ni}$ as show in Figures $9 \mathrm{a}$ and 10a). In the surface area, there are few $\mathrm{Cr}$ and $\mathrm{Ni}$ elements because these elements are mixed in the original ductile cast iron based on the ASTM 536 standard. It can be seen that $\mathrm{Cr}$ and $\mathrm{Ni}$ elements dominate all specimens in the centre and surface area. Solidification temperature and elemental content affect the formation of ferro carbide in the matrix, besides that the $\mathrm{Cr}$ and Carbon content affect the atomic diffusion process in the $\mathrm{M}_{7} \mathrm{C}_{3}$ carbide matrix as described by Li P. et al. [39].

The result of the diffusion contains $2.04 \% \mathrm{Cr}$ and a little $0.26 \% \mathrm{Ni}$ formed on the local of the surface of sample S1, quantify by EDX as shown in Figures $10 \mathrm{~b}$ and $9 \mathrm{~b}$. The formation of the alloy composition elements is caused by the diffusion of the chill material elements when the preheating temperature distribution is $500^{\circ} \mathrm{C}$ to the surface of the chill plate. Also, the average amount of microhardness achieved is $500 \mathrm{HV}$. But there were also some test zones where the hardness value was found to be $700 \mathrm{HV}$.

The sample for use preheating temperature $700^{\circ} \mathrm{C}(\$ 2)$, that the element diffusion formed on the surface layer consists of the content of $3.23 \% \mathrm{Cr}$ and $0.97 \% \mathrm{Ni}$ as shown in Figures 10c and 9c. The alloy formation of the composition elements is higher than using a temperature of $500^{\circ} \mathrm{C}$. After several microhardness tests were carried out that the average hardness value was 500 and certain areas had the highest hardness randomly reaching $800 \mathrm{HV}$.

Sample S3 shows that the result of diffusion formed a $\mathrm{Cr}$ content of $7.13 \%$ and $0.21 \% \mathrm{Ni}$ as shown in Figures $10 \mathrm{~d}$ and $9 \mathrm{~d}$. The alloy formation of the composition elements is higher than using temperatures of $700^{\circ} \mathrm{C}$ and $500^{\circ} \mathrm{C}$. Diffusion of $\mathrm{Cr}$ and $\mathrm{Ni}$ elements by using preheating temperature of $900^{\circ} \mathrm{C}$ to the chill face and ductile iron has an average microhardness is $900 \mathrm{HV}$. The highest hardness values found in the few areas reached $939.3 \mathrm{HV}$. By using the higher diffusion temperatures will increase higher hardness, as research conducted by Ali Günen et al [40]. Details of the three EDX spectra and different temperature preheating of the element formed on the surface zone are listed in Table 3. EDX weight ratio of elements deposition $(\mathrm{Cr}, \mathrm{Ni}$, and $\mathrm{C})$ using three spectrums focused on three distinct areas then the average will be taken for comparison. EDX detects the Chromium value shown in Table 3, that is for the $S 3$ sample by using a preheating temperature of $900^{\circ} \mathrm{C}$, the diffused chromium element is $7.13 \%$, EDX analysis results show that, in the surface area of nodular cast iron, iron carbide has been formed which is white mixed with grey colour as show in Figure 9d, the type of the structure matrix is $(\mathrm{FeCr}) 7 \mathrm{C} 3$, as described by Lagos $\mathrm{M}$. A. et al [41] that iron-chromium carbide is very hard and good for wear, abrasion, corrosion and oxidation resistance. High chromium alloys will have an impact on the formation of chromium carbide with high hardness but depending on the content of carbon and other elements, the lower carbon value will reduce the formation of $M_{7} C_{3}, M_{23} C_{6}$, and $\mathrm{M}_{3} \mathrm{C}$, in the coating area, as research conducted by Jillah, A. et al. and Li, $\mathrm{Y}$ et al. [42, 43]. Besides that, there is also a Nickel $(\mathrm{Ni})$ content, its function is to extend the austenite field. Nickel has no impact on the carbide formation process because the Nickel content in the diffusion layer is very small.

Table 3: EDX weight ratio of elements deposition $(\mathrm{CrNi})$ using three spectrums focused on three distinct areas of surface for all specimens.

\begin{tabular}{|c|c|c|c|c|c|c|c|c|}
\hline \multirow{2}{*}{$\begin{array}{l}\text { Temperature } \\
\text { preheating }\end{array}$} & \multicolumn{2}{|c|}{ Carbon (C) } & \multicolumn{2}{|c|}{ Silicon (Si) } & \multicolumn{2}{|c|}{ Chromium (Cr) } & \multicolumn{2}{|c|}{ Nickel (Ni) } \\
\hline & $\begin{array}{c}\text { Weight } \\
(\%)\end{array}$ & $\begin{array}{l}\text { Atomic } \\
(\%)\end{array}$ & $\begin{array}{l}\text { Weight } \\
(\%)\end{array}$ & $\begin{array}{l}\text { Atomic } \\
(\%)\end{array}$ & $\begin{array}{l}\text { Weight } \\
(\%)\end{array}$ & $\begin{array}{c}\text { Atomic } \\
(\%)\end{array}$ & $\begin{array}{l}\text { Weight } \\
(\%)\end{array}$ & $\begin{array}{c}\text { Atomic } \\
(\%)\end{array}$ \\
\hline $\begin{array}{l}\text { Not using } \\
\text { preheating }\end{array}$ & 18.67 & 47.53 & 1.98 & 2.16 & 0.13 & 0.08 & 0.11 & 0.06 \\
\hline $500^{\circ} \mathrm{C}$ & 26.01 & 57.93 & 1.65 & 1.57 & 3.93 & 2.04 & 0.56 & 0.26 \\
\hline $700^{\circ} \mathrm{C}$ & 14.77 & 40.83 & 1.79 & 2.11 & 5.06 & 3.23 & 1.72 & 0.97 \\
\hline $900^{\circ} \mathrm{C}$ & 27.88 & 46.58 & 0.78 & 0.87 & 11.85 & 7.13 & 0.40 & 0.21 \\
\hline
\end{tabular}



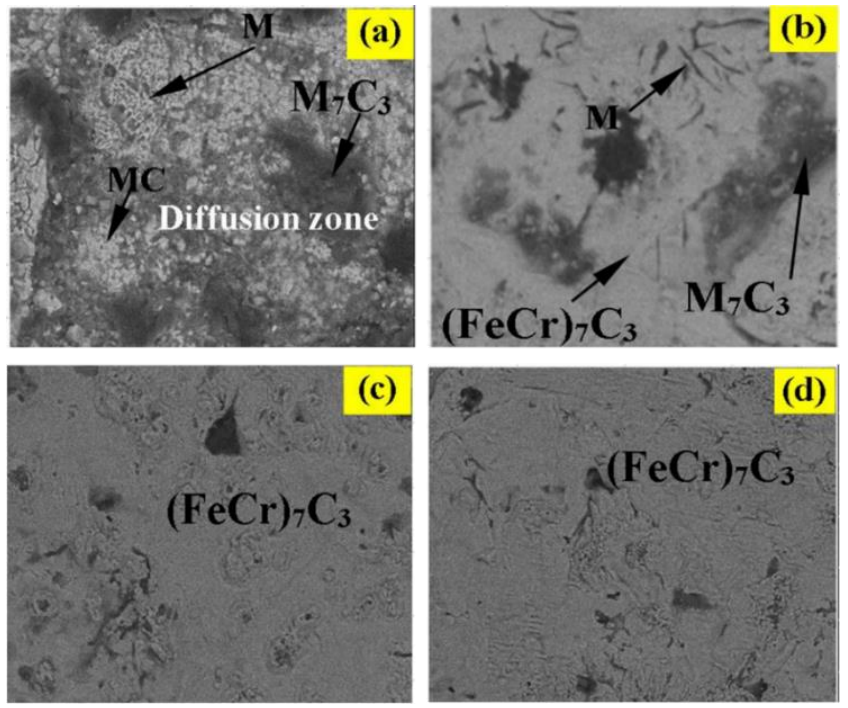

Figure 9: Energy Dispersive X-Ray (EDX) analysis to quantify the deposition of atom on the diffusion zone. (a) Sample S4, (b) Sample S1, (c) Sample S2, (d) Sample S3. (M: martensite, MC: metal carbide).
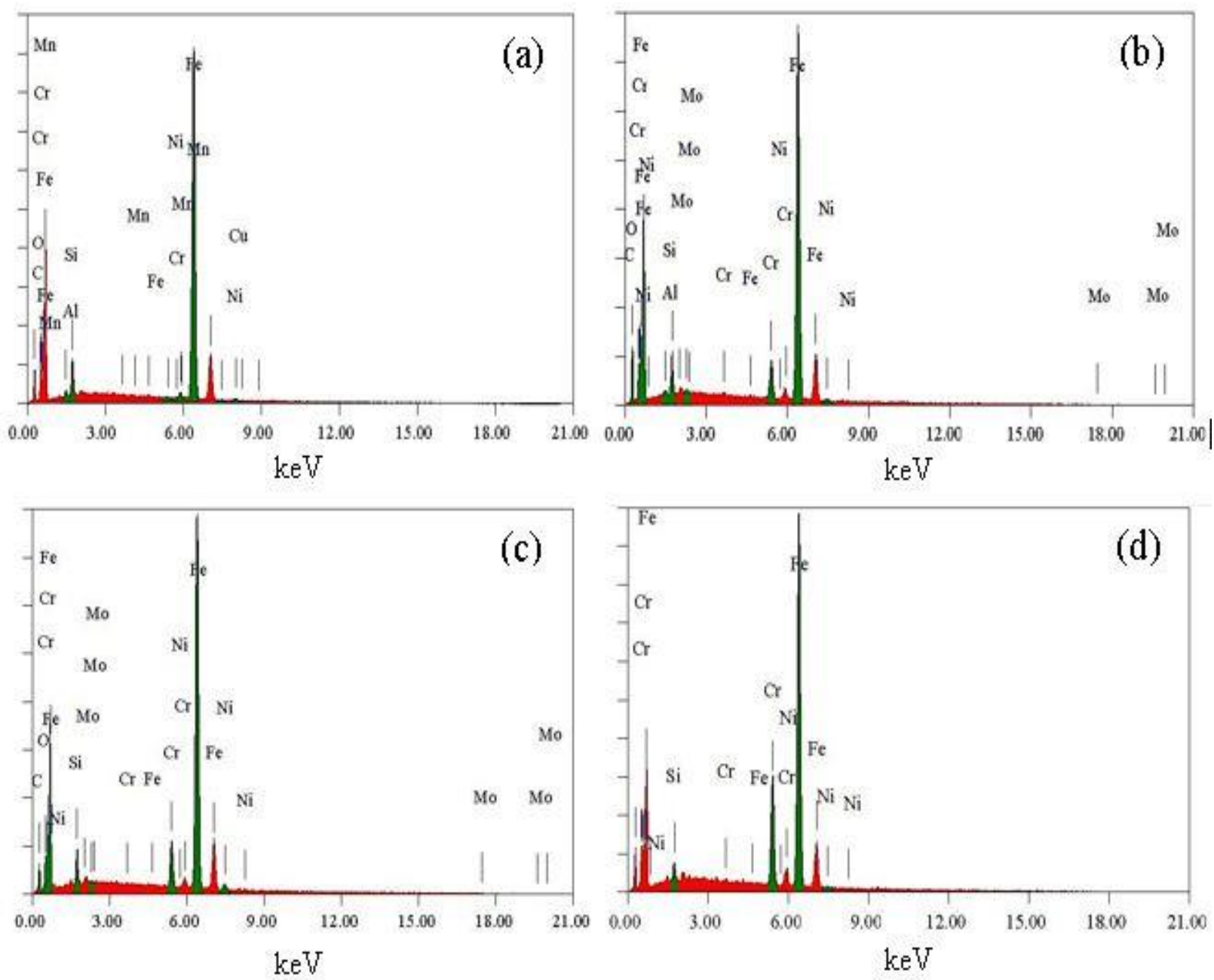

Figure 10: Energy Dispersive X-Ray (EDX) analysis to quantify the deposition of atom on the surface. (a) Sample S4, (b) Sample S1, (c) Sample S2, (d) Sample S3. (M: martensite, MC: metal carbide). 


\subsection{The Thickness Layer Measurement}

The measurement process using SEM Cross-section for sample 54 were not using preheating before the pouring process, although not using preheating, the casting process still uses plate chill, so that the results can be compared with other parameters. The results obtained are an average thickness value of $0.011 \mathrm{~mm}$ from ten measurements, while the deviation value was $1.72 \mathrm{~mm}$ as show in Figure 11a).

SEM Cross-section analysis results for $\mathrm{S} 1$ samples using $500^{\circ} \mathrm{C}$ preheating temperature is an analysis of the position of the cross-section with an average thickness distance of $0.012 \mathrm{~mm}$ from 10 measurements and a deviation value of $0.001 \mathrm{~mm}$. Measurements were made on the white layer area, as shown in Figure 11b.

The results for $\$ 2$ samples with a preheating temperature of $700^{\circ} \mathrm{C}$ obtained an average thickness of coating layer of $0.015 \mathrm{~mm}$ from 10 measurements and a deviation value of $1.165 \mathrm{~mm}$. Measurements were made on the white layer area as show in Figure 11c). Meanwhile, there is a deposition of $\mathrm{Cr}$ and $\mathrm{Ni}$ elements on the surface, resulting in high hardness. Things related to the research of Silva Leandro J. da L et al. [44] and Janicki D. Et al. [45] that the good bonding of the elements and the number of coated particles on the surface largely determine wear performance.

The results for sample $S 3$ using a preheating temperature of $900^{\circ} \mathrm{C}$ obtained an average layer thickness on the white layer at the edge of the surface areas, reaching $0.020 \mathrm{~mm}$ from 10 measurements to obtain the average value. The deviation value is $0.001 \mathrm{~mm}$, as shown in Figure 11d. By using a preheating temperature of 900 has produced a high thickness of the iron carbide layer when compared to using a lower preheating temperature. These results will predict resistance to contact fatigue loads on components, based on the research of Li W. et al. [46] and Rajinikanth V. et al. [47] that the elements that diffuse to the surface are deeper or thicker, this will be occurring resistant to contact fatigue loads.
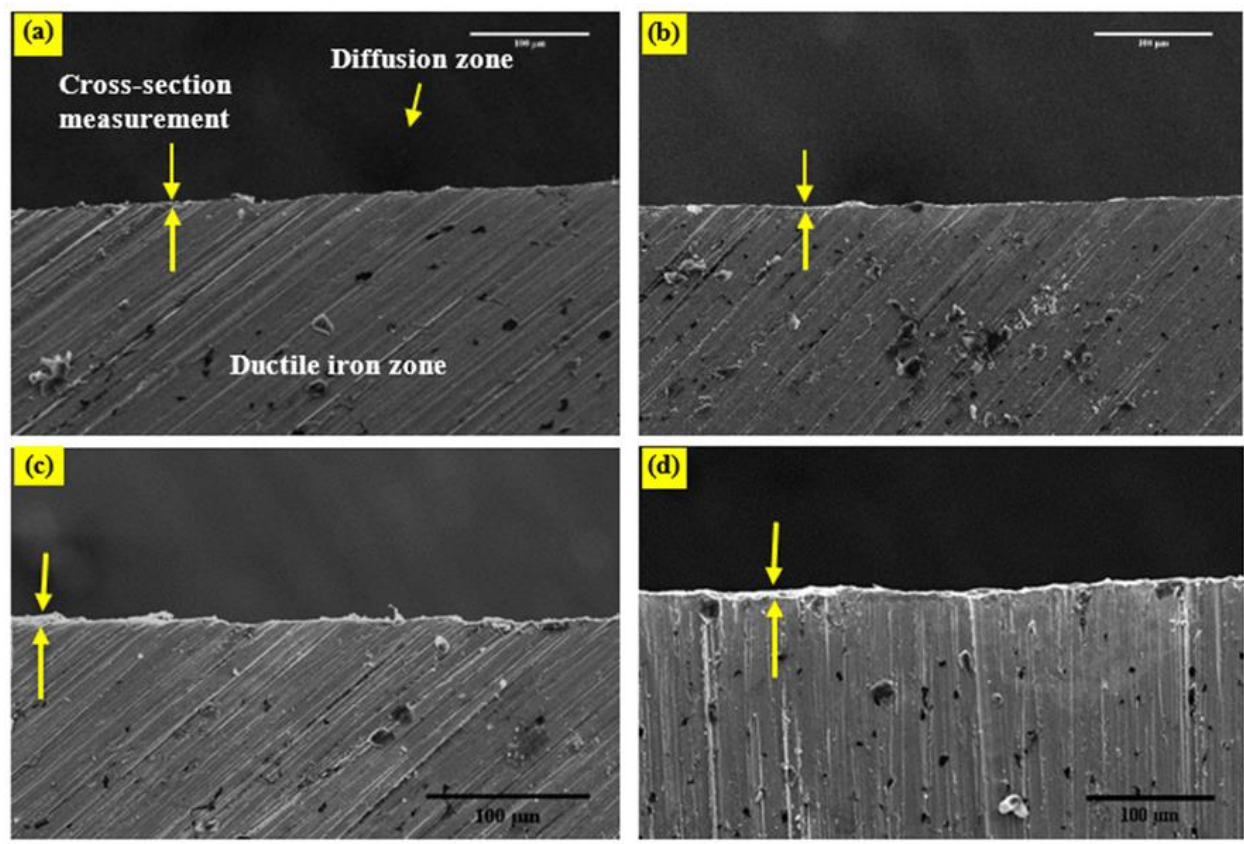

Figure 11: The thickness layer analysis by cross-section testing. (a) thickness layer of sample not using preheating process (S4), (b) thickness layer of the sample by using temperatur preheating $500^{\circ} \mathrm{C}(\mathrm{S} 1$ ), (c) the thickness layer of the sample by using temperatur preheating $700^{\circ} \mathrm{C}(\mathrm{S} 2)$, (d) the thickness layer of the sample by using temperatur preheating $900^{\circ} \mathrm{C}(53)$.

\section{CONCLUSIONS}

This research described investigations related to variations in preheating temperature on chill plates against hardness values, surface layer thickness, and chemical diffusion on ductile cast iron surfaces. Therefore, the following conclusions were drawn:

1. By using the preheating method for the chill plate before the pouring process, it has resulted in a different surface layer by not using preheating.

2. Compared with do not use preheating proses on the chill plate, the formation of a carbide eutectic structure on the surface of Y-Block specimens with a thickness of $0.012 \mathrm{~mm}$ to $0.020 \mathrm{~mm}$, increases the hardness up to $900 \mathrm{HV}$. Furthermore, by preheating, it can diffuse Chromium elements onto the ductile iron surface to form $(\mathrm{FeCr})_{3} \mathrm{C}$ and $(\mathrm{FeCr})_{7} \mathrm{C}_{3}$ structures called ledeburite structures, which are categorized as white cast iron with a high hardness. 
3. High preheating temperatures increase the thickness of the hardness layer on the ductile iron surface and raise the high hardness value on the surface. The higher preheating temperature used, the greater the chromium element's ability that diffuses to the ductile iron surface to reach $7.13 \%$. Furthermore, the increase in the chromium element's value leads to the formation of $a(F e C r){ }_{7} C_{3}$ structure, thereby increasing the high hardness value on the surface.

4. The results obtained, this method can be applied to surface hardening of components that require high wear resistance such as gears, hot rolling mills, crankshafts, bearings, cylinder blocks, and others.

\section{ACKNOWLEDGEMENT}

The study was carried out with partial financial support provided by the Dili Institute of Technology Timor Leste and Fundo de Desenvolvimento do Capital Humano (FDCH) Timor Leste. We also thank to Diponegoro University and Politeknik Manufacture Ceper for supporting the laboratory of testing.

\section{REFERENCES}

1. Lyle R. Jenkins. Properties and Selection: Irons, Steels, and High-Performance Alloys, 10th Edition. ASM International the Materials Information Company, United State of America, 1992, pp. 224-238.

2. Wang, Ben L., Morris, Dallin S., Farshid, S., Lortz, S., Ma, Q., Wang, C., Chen, Yong-ching., Sanders, P.: Rolling contact fatigue study of chilled and quenched/tempered ductile iron compared with AISI 1080 steel, Wear. Elsevier, 2021, 478-479, p. 203890.

3. Durand-Charre, M. Microstructure of Steels and Cast Irons. Springer- Verlag Berlin Heidelberg New York Cataloging-in-Publication, Germany, 2004, pp. 419.

4. Wankhede, D.M. Narkhede, B.E., and Mahajan, S.K. Investigation of Casting Parameters and External Chills Performance on Mechanical Properties of Aluminum Silicon Alloy (LM6) Castings 4-8, 2017.

5. Wankhede, D.M. Narkhede, B.E., Mahajan, S.K., and Choudhari, C.M. Influence of pouring temperature and external chills on mechanical properties of aluminum silicon alloy castings. Mater. Today Proc. 5, 2018, pp. 17627-17635.

6. Pavithra, H.S. and Anantha Prasad, M.G. Study on Microstructure and Mechanical Properties of Al/SiO2/C hybrid metal matrix composite, with the Influence of Chills. Mater. Today Proc. 5, 2018, pp. 6053-6058.

7. Gafur, M.A., Haque, M.N. and Prabhu, K.N. Effect of chill thickness and superheat on casting/chill interfacial heat transfer during solidification of commercially pure aluminium. J. Mater. Process. Technol. 133, 2003, pp. 257-265.

8. Kanthavel, K., Arunkumar, K. and Vivek, S. Investigation of chill performance in steel casting process using Response Surface Methodology. Procedia Eng. 97, 2014, pp. 329-337.

9. Fischer, S.F., Muschna, S., Bührig-Polaczek, A. and Bünck, M. In-situ surface hardening of cast iron by surface layer metallurgy. Mater. Sci. Eng. A 615, 2014, pp. 61-69.

10. Oloyede, O., Cochrane, R.F. and Mullis, A.M. Effect of rapid solidification on the microstructure and microhardness of BS1452 grade 250 hypoeutectic grey cast iron. J. Alloys Compd. 707, 2017, pp. 347-350.

11. Kumruoğlu, L.C. Mechanical and microstructure properties of chilled cast iron camshaft: Experimental and computer aided evaluation. Mater. Des. 30, 2009, pp. 927-938.

12. Sonne, M.R., Frandsen, J.O. and Hattel, J.H. Comparison of residual stresses in sand- and chill casting of ductile cast iron wind turbine main shafts. IOP Conf. Ser. Mater. Sci. Eng. 2015 pp. 84.

13. Dobrovska, J., Kavicka, F., Stransky, K., Sekanina, B., and Stetina, J. Numerical optimization of the method of cooling of a massive casting of ductile cast-iron. AIP Conf. Proc. 1252, 2010, pp. 578-585.

14. Hayrynen, K.L. and Brandenberg, K.R. Carbidic Austempered Ductile Iron (CADI). Trans. Am. Foundry Soc. 111, 2003, pp. 1-6.

15. Labrecque, C., Gagné, M., Javaid, A. and Sahoo, M. Production and properties of thin-wall ductile iron castings. Int. J. Cast Met. Res. 16, 2003, pp. 313-317.

16. Hurst S. METAL CASTING Appropriate technology in the small foundry. Intermediate Technology Publications Ltd, London-UK, 1996, pp.240.

17. Laino, S., Sikora, J.A. and Dommarco, R.C. Development of wear resistant carbidic austempered ductile iron (CADI). Wear 265, 2008, pp. 1-7.

18. Qian, M., Harada, S., Kuroshima, Y., Shoji Harada and H. Nagayoshi. Surface hardening of ductile cast iron using stainless steel. Mater. Sci. Eng. A 208, 1996, pp. 88-92.

19. Radzikowska, J.M. and Foundry, T. Metallography and Microstructures of Cast Iron, ASM Handbook, Volume Metallography and Microstructures. ASM International, Kingdom, 2004, pp 565-587.

20. König, Mathias, Ingvar L Svensson, and Wessén M. The Influence of Alloying Elements on Chill Formation in CGI. 457, 2011, pp. 126-31.

21. Mattox, D.M. ASM Handbook Vol. 5 Surface Engineering, 9th Edition. ASM International, United State of America 1994, pp. 1538-1539. 
22. Gao, X., Jiang, Z., Wei, D., Jiao, S., Chen, D., Xu, J., Zhang, X. and Gong, D. Effects of temperature and strain rate on microstructure and mechanical properties of high chromium cast iron/low carbon steel bimetal prepared by hot diffusion-compression bonding. Mater. Des. 63, 2014, pp. 650-657.

23. Ramadan, M. Interface Structure and Elements Diffusion of As-Cast and Annealed Ductile Iron/Stainless Steel Bimetal Castings. Engineering, Technology \& Applied Science Research 8 (2): 2018, pp. 2709-14.

24. Shi Z., Shao, W., Rao, L., Hu, T., Xing, X., Zhou, Y., Liu, S. and Yang Q. Effects of Ce Doping on Mechanical Properties of M7C3 Carbides in Hypereutectic Fe-Cr-C Hardfacing Alloy. Journal of Alloys and Compounds 850: 156656, 2021.

25. Riposan L., Stan S., Chisamera M., Neacsu L., Maria Cojocaru A., Stefan E., and Stan I. Simultaneous Thermal and Contraction/Expansion Curves Analysis for Solidification Control of Cast Irons. China Foundry 17 (2): 2020, 96-110.

26. Smita G. Rao, Rui Shu, Robert Boyd, Grzgorz Greczynski, Arnaud le Febvrier, Per Eklund. Phase Formation and Structural Evolution of Multicomponent ( $\mathrm{CrFeCo}$ )Ny Film. Building and Environment 184 (August): 107229, 2021.

27. ASTM A 536. Standard Specification for Ductile Iron Casting, 2004.

28. William D. Callister and David G. Rethwisch. Materials Science and Engineering an Intruduction, Eighth Edition, Jhon Wiley and Sons, Inc, United States of America, 2010, pp. 403.

29. ASTM A240. Standard Specification for Chromium and Chromium-Nickel Stainless Steel Plate, Sheet, and Strip for Pressure Vessels and for General Applications. ASTM International, United State of America, 2015.

30. Radzikowska, Janina M. and the Foundry. Metallography and Microstructures of Cast Iron. ASM Handbook, Volume 9: Metallography and Microstructures. Kingdom: ASM Internasional 2004, pp. 565-587.

31. ASTM A247 - 03A. Standard Test Method for Evaluating the Microstructure of Graphite in Iron Castings 1, American Society for Testing and Materials, 1998.

32. ASTM-E92. Standard Test Method for Vickers Hardness of Metallic Materials. ASTM International 82 (Reapproved): 1997, 1-10.

33. Gou, J., Wang, Y., Sun, J. and Li, X. Bending strength and wear behavior of Fe-Cr-C-B hardfacing alloys with and without rare earth oxide nanoparticles. Surf. Coatings Technol. 311, 2017, pp. 113-126.

34. Yamamoto, S., Chang, B., Kawano, Y., Ozaki, R., Murakami, Y. Mechanism of Nodularization of Graphite in Cast Irons Treated with Magnesium. Metal Science 12 (5), 1978, 239-46.

35. Sasaki, Hideaki, Matsumoto, M. Nodulization of Graphite in Cast Iron by Addition of Plastic Resin." Materials Letters 270: 127708, 2020.

36. Liu J. H., Jian S. Y., Xue B. Z., Bin G. F., Hai T. X., Gui X. Z., and Peng H. Y. Precipitation and Evolution of Nodular Graphite during Solidification Process of Ductile Iron. China Foundry 17 (4): 2020, 260-71.

37. Voort, V., Baldwin, W. Metallography and Microstructures ASM Handbook, ASM International. ASM International, United State of America, 2004, pp. 565-568.

38. Pero-Sanz Elorz, José Antonio, Daniel Fernández González, and Luis Felipe Verdeja. Physical Metallurgy of Cast Irons. Physical Metallurgy of Cast Irons, Springer International Publishing AG, p. 153-190, 2020.

39. Li P., Yang, Y., Shen, D., Gong, M., Tian, C. and Tong, W. Mechanical Behavior and Microstructure of Hypereutectic High Chromium Cast Iron: The Combined Effects of Tungsten, Manganese and Molybdenum Additions. Journal of Materials Research and Technology 9 (3), 2020.

40. Günen, A., Kalkandelen, M. Karahan, I. H., Kurt, B., Kanca, E., Gök, M. S. and Karakaş, M. S. Properties and Corrosion Behavior of Chromium and Vanadium Carbide Composite Coatings Produced on Ductile Cast Iron by Thermoreactive Diffusion Technique. Journal of Engineering Materials and Technology, Transactions of the ASME 142 (4), 2020.

41. Lagos, M. A. et al.: Fabrication of chromium carbide cermets by electric resistance sintering process: Processing, microstructure and mechanical properties', International Journal of Refractory Metals and Hard Materials. Elsevier Ltd, 95 (October 2020), p. 105417, 2021.

42. Jilleh, A., Babu, N. K., Thota, V., Anis, A. L., Harun, M. K. and Talari, M. K. Microstructural and Wear Investigation of High Chromium White Cast Iron Hardfacing Alloys Deposited on Carbon Steel. Journal of Alloys and Compounds 857: 157472, 2021.

43. Li, Y., Shen, D., Xu, N. and Tong, W. Cladding High Chromium Cast Irons on Low Carbon Steel: Microstructure and Mechanical Properties. Journal of Materials Research and Technology 9 (3), 2020, 3856-64.

44. Silva, Leandro J. da, Cristiano J. Scheuer, and Ana Sofia C.M. D'Oliveira. Effect of Microstructure on Wear Performance of NiCrSiBC Coatings. Wear 428-429 (March), 2019, 387-94.

45. Janicki, D.: The friction and wear behaviour of in-situ titanium carbide reinforced composite layers manufactured on ductile cast iron by laser surface alloying, Surface and Coatings Technology. Elsevier B.V., 406 (November), 2021, p. 126634.

46. Li, W., Deng, S. and Liu, B.: Experimental study on the influence of different carburized layer depth on gear contact fatigue strength, Engineering Failure Analysis. Elsevier Ltd, 107, p. 104225, 2020.

47. Rajinikanth, $\mathrm{V}$. et al. (2021) 'Microstructural investigation of rolling contact fatigue (RCF) on a failed planetary gear of a windmill gearbox', Engineering Failure Analysis. Elsevier Ltd, 121(October 2020), p. 105167. 